\title{
A Novel Grip Design for High-Accuracy Thermo-Mechanical Tensile Testing of Boron Steel under Hot Stamping Conditions
}

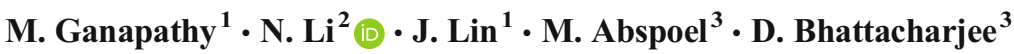

Received: 28 November 2016 / Accepted: 21 August 2017 /Published online: 4 October 2017

(C) The Author(s) 2017. This article is an open access publication

\begin{abstract}
Achieving uniform temperature within the effective gauge length in thermo-mechanical testing is crucial for obtaining accurate material data under hot stamping conditions. A new grip design for the Gleeble Materials-Simulator has been developed to reduce the long-standing problem of temperature gradient along a test-piece during thermomechanical tensile testing. The grip design process comprised two parts. For the first part, the new design concept was analysed with the help of Abaqus coupled Thermal-Electric Finite element simulation through the user defined feedback control subroutine. The second part was Gleeble thermomechanical experiments using a dog-bone test-piece with both new and conventional grips. The temperature and strain distributions of the new design were compared with those obtained using the conventional system within the effective gauge length of $40 \mathrm{~mm}$. Temperature difference from centre to edge of effective gauge length (temperature gradient) was reduced by $56 \%$ during soaking and reduced by $100 \%$ at $700{ }^{\circ} \mathrm{C}$. Consequently, the strain gradient also reduced by $95 \%$, and thus facilitated homogeneous deformation. Finally to correlate the design parameters of the electrical conductor used in the new grip design with the geometry and material of test-piece, an analytical relationship has been derived between the testpiece and electrical conductor.
\end{abstract}

N. Li

n.li09@imperial.ac.uk

1 Department of Mechanical Engineering, Imperial College London, London SW7 2AZ, UK

2 Dyson School of Design Engineering, Imperial College London, London SW7 2AZ, UK

3 Tata Steel, IJmuiden, The Netherlands
Keywords Grip design · Thermo-mechanical testing · Temperature fields $\cdot$ Boron steel $\cdot$ Hot stamping · Electrical-resistance heating

\section{Introduction}

Current global emission regulations are driving automotive industries to improve fuel efficiency and reduce $\mathrm{CO}_{2}$ emissions of their vehicles, while passenger safety guidelines are forcing the car manufacturers to increase the level of passenger safety by increasing crashworthiness. Achieving both environmental and safety norms simultaneously is a major challenge for car manufacturers, since the two goals impose conflicting requirements, reduced weight and increased strength, on vehicle design [1]. To meet the mandatory regulations in both aspects, use of thin ultra-high-strength steel (UHSS), for body and chassis parts, is a solution for auto manufacturers. Manufacture of lightweight components made of UHSS in traditional cold stamping is limited by poor formability and excessive spring-back of the workpiece material. To overcome these drawbacks, hot stamping technology has been developed in the recent decade and is now widely used $[2,3]$.

Figure 1(a) shows the temperature profile of a work-piece in a typical hot stamping process of press hardening steel. The work-piece initially has a ferrite and pearlite microstructure and is heated to above the austenite transformation temperature (usually about $900{ }^{\circ} \mathrm{C}$ in production) and held for few minutes to achieve the austenite phase throughout its volume. Then the blank is quickly transferred from the furnace to the cold stamping tool, and is deformed into the required shape, while being rapidly quenched $\left(>27^{\circ} \mathrm{C} / \mathrm{s}\right)$ within the tools to produce a final product predominately with a martensitic phase [4]. 
(a)

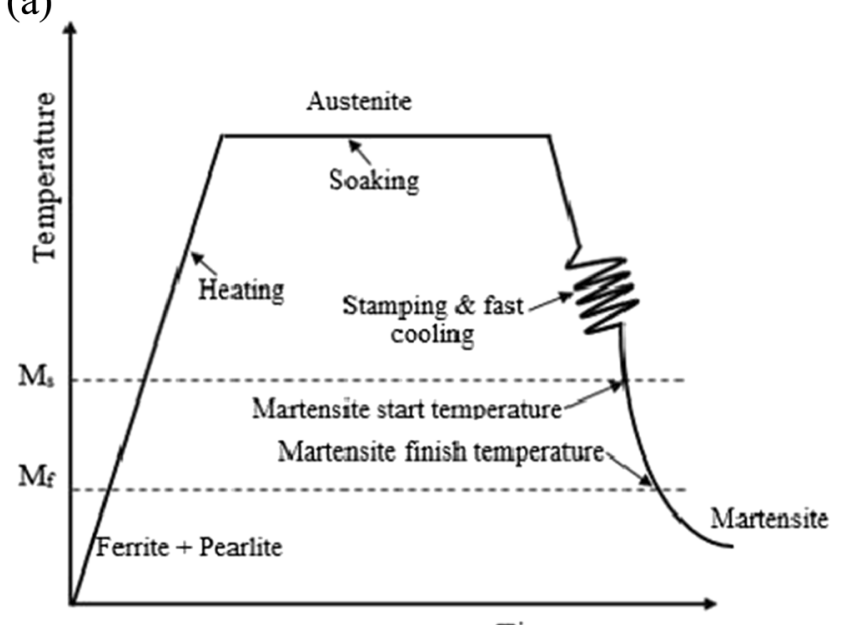

Time

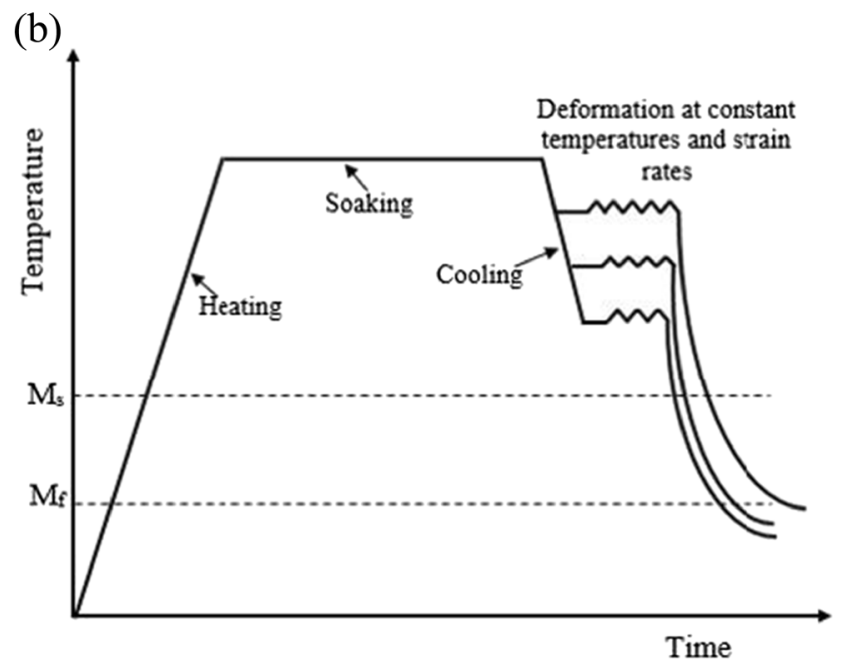

Fig. 1 Temperature profiles in (a) a typical hot stamping process; and (b) typical thermo-mechanical testing to simulate hot stamping process for boron steel

To design a robust efficient hot stamping process, finite element simulations are used. A series of advanced unified visco-plastic constitutive material models have been proposed [5-9] for hot stamping simulation which address many timedependent material mechanisms, for example, diffusion, recovery, recrystallization and grain growth. The metallurgical evolutions result in the force required for plastic deformation being time and deformation speed/strain rate, dependent [10]. Material mechanical property data used in these models has been obtained from tensile tests in which test-pieces undergo the temperature profile of the form shown in Fig. 1(b). In order to characterise properties of boron steel for hot stamping condition, rapid heating, soaking, and cooling of a test-piece must be an integral part of a uniaxial tensile test; therefore, conventional hot uniaxial testing which is operated in an oven or furnace is unsuitable. Performing uniaxial tests in the Gleeble Materials-Simulator can be considered as means of achieving suitable test conditions, since the machine can rapidly heat and cool a test-piece at any stage in the temperature cycle. In complex stamping, material is subjected to complex loading paths. The Gleeble-based test methodology can be used for both uniaxial and bi-axial testing. A novel biaxial testing system for use in Gleeble testing machine has been developed for practical hot stamping conditions [11].

In a Gleeble, heating a test-piece to the target temperature is done by direct electrical resistance heating through the grips at each end, but test-piece temperature is not uniform along its gauge length due to heat loss to the water cooled copper jaws, through which power is supplied, supporting the grips, as shown in Fig. 2(a). An overview of temperature distributions along uniaxial test-pieces found in the literature [12-14] is shown in Fig. 2(b). For large temperature gradients, the metallurgical state of the middle part of a test-piece could be austenite and the ends, near the grips, ferrite [15]. And ferrite can be softer than

(a)

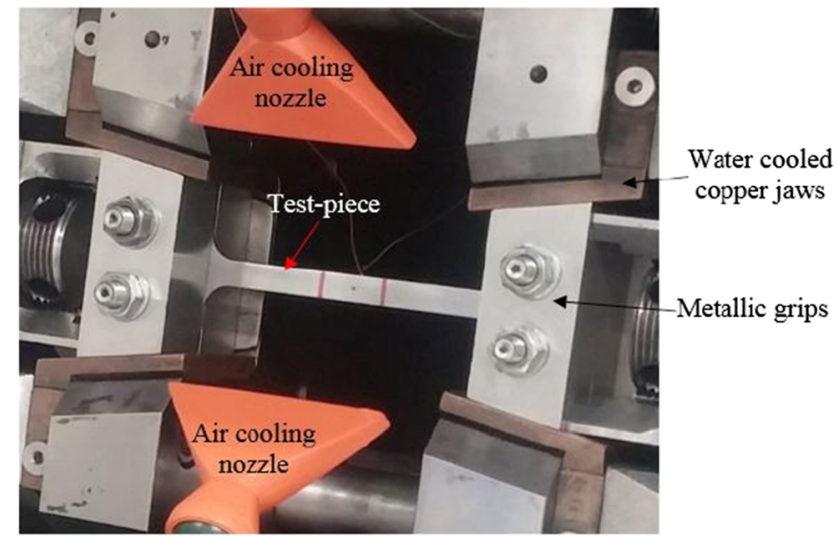

(b)

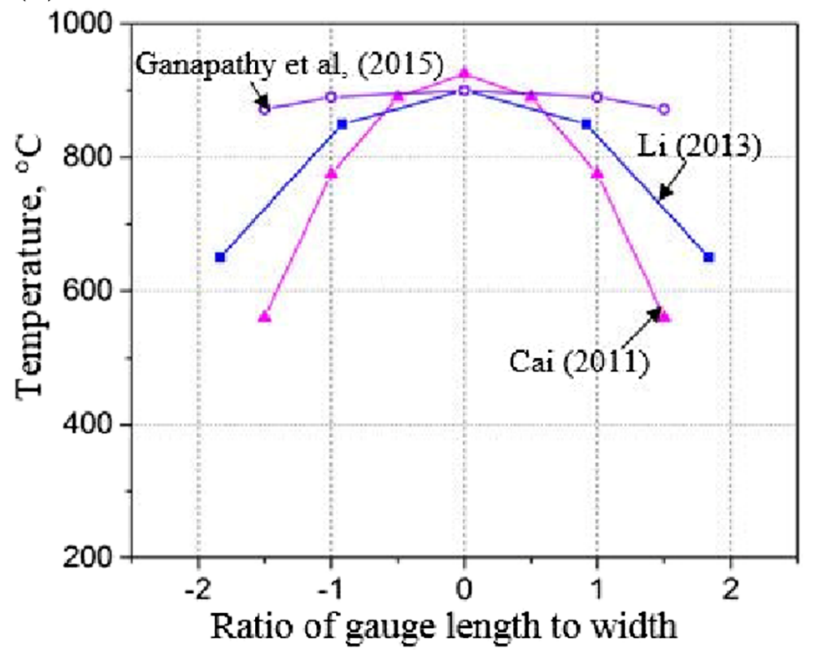

Fig. 2 (a) Gleeble test setup with conventional grips; and (b) Test-piece temperature profile from various test results [12-14] 
austenite for certain temperature ranges [16]. Thus strain could be greater in the ferrite and non-uniform deformation along a test-piece result in calculation of erroneous stressstrain data, for use in simulations. A systematic analysis of error can be found in reference [17].

Extensive research and development of modified test-piece geometry and grips, has been undertaken to reduce thermal gradients in tensile test-pieces. For example, Walsh et al. showed that, longer jaw separation, higher test temperature, smaller test-piece diameter, and lower test-piece thermal diffusivity, enhance temperature uniformity. Any measure that reduces thermal conductivity at the jaw will promote the constant temperature region [18]. Brown, et al. simulated the effect of heat transfer co-efficient of grip material on thermal behaviour of test-pieces. Their study indicated that grips influence the rate of diffusive heat loss and the temperature distributions within a test-piece [19]. Norris et al. simulated the thermal behaviour of various Gleeble test-pieces to optimize a Gleeble test-piece design and found that the temperature gradient and the magnitude of this gradient dependent on the gripping material used [20]. Zupan et al. and Karanjgaokar et al. conducted thermo-mechanical tensile tests with micro machined metal samples using electrical resistance heating and observed non-uniform strain due to significant temperature gradients within a gauge length [21, 22].

Lindeman et al. proposed a technique for applying direct resistance heating current to particular locations in test-pieces and substantially reduced thermal gradients [23]. Ferguson et al. suggested an apparatus that provides enhanced selfresistive test-piece heating when used in a conventional thermo-mechanical material testing system for greater temperature uniformity throughout a test-piece [15]. Shen et al. concluded that the primary factor influencing uniform temperature, is the free span between jaws [24]. Li et al. proposed a set of stainless steel grips integrated with grooves and textured surface to reduce the contact area between the grips and dogbone shaped work-piece with large parallel length $(80 \mathrm{~mm})$, to reduce temperature gradients. Uniformity of temperature was improved and an effective gauge length of $14 \mathrm{~mm}$ with temperature gradient less than $10^{\circ} \mathrm{C}$ was achieved; however, with the gauge width of $8 \mathrm{~mm}$, the ratio of (effective gauge length / gauge width) was less than 2 and apparently a better temperature uniformabity is desired [25]. Abspoel et al. proposed a new test-piece design, which can achieve equal current density by adding a pair of shunt connections, in order to achieve a uniform temperature along the test-piece [26]. Ganapathy et al. analysed the design and found that Abspoel test-piece was able to achieve a uniform temperature over the $30 \mathrm{~mm}$ gauge length (with the gauge width of $10 \mathrm{~mm}$ ), and thus obtained a better uniform strain distribution over the test-piece gauge length [14]. However, the test-piece is in complex geometry without test standards to refer to; at the same time, the set-up is complicated and time-consuming. To address the aforementioned problems, the main aim of this paper is to design and develop a set of novel grips which enables a simple tensile test-piece design to be used to achieve uniform temperature through resistance heating, on a Gleeble, under hot stamping conditions.

\section{Design of New Uniaxial Test Grips}

To overcome the limitations of the existing conventional grips used for thermo-mechanical uniaxial tests, a novel set of grips, for hot tensile testing on a Gleeble have been developed. A schematic illustrating the concept of the self-resistance heating grips is shown in Fig. 3(a). The concept of the grips that hold the test-piece is that they do not rapidly loose heat to the copper jaws. Thus they are made of electrically nonconducting and heat insulating material so that electrical current to heat the test-piece can no longer pass directly from the copper jaws, through metal grips to the test-piece, as in the conventional design. Instead, a conductor of the electrical supply, from copper jaw to test-piece is made of a network of long branches of small cross-sectional area that are wrapped around the grips. Thus, while the electrical supply still heats the test-piece, heat generated due to the raised resistance of the conductor heats the grips also and because the grips are poor conductors of heat, little is lost to the water cooled grips, as in the conventional set-up. More electrical energy is supplied to generate higher heat energy; second, the heat loss to water cooled jaws from test-piece is reduced. Both concepts are further discussed, which leads to the detailed design, in the following subsections. The quantitative relation of design parameters and heat generation/loss is analysed.

\section{Improvements for Higher Heat Generation}

Electrical current is passed through the metallic test-piece. Due to electrical resistance, the supplied electrical energy is converted into heat energy. The amount of heat released is proportional to the square of the current and the resistance as described by equation (1).

$P=I^{2} * R$

Where ' $P$ ' is Electrical power dissipation, ' $T$ ' is Electrical current, ' $R$ ' is Electrical resistance.

To generate higher heat around the grips, the overall resistance of the electrical circuit is increased by using slim branches in the conducting network. With a higher overall resistance, electrical power required to heat the test-piece to the target temperature is also higher. Increased electrical resistance and power, the heat generation is also much higher than conventional test method. The excess heat produced around the grips can compensate the heat loss by a water cooled 
(a)

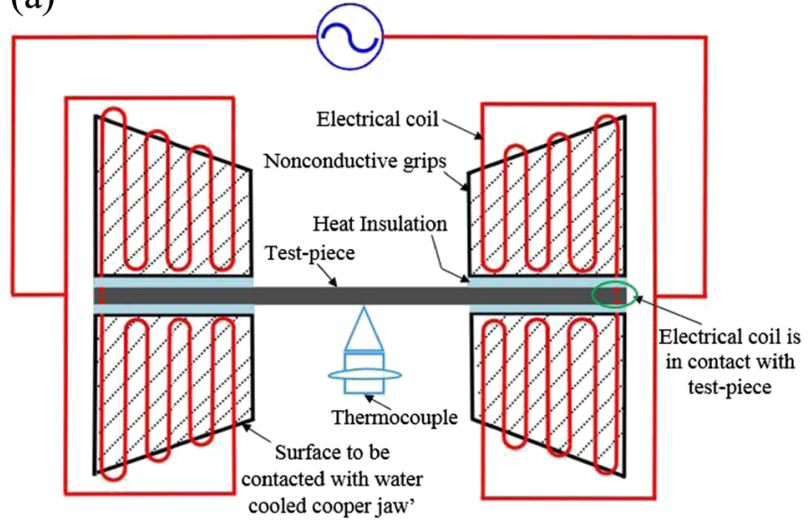

(b)

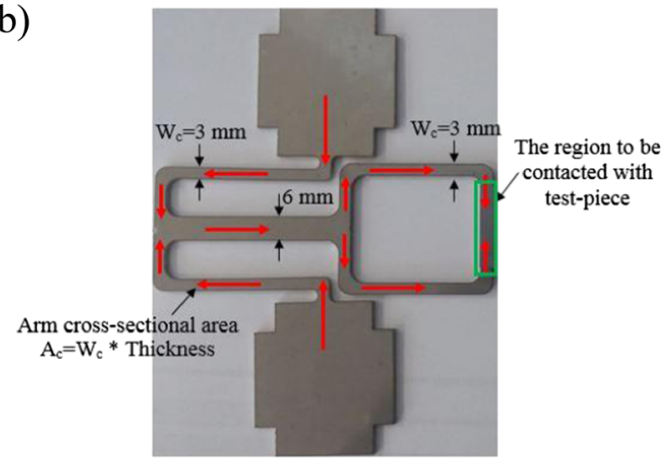

(c)

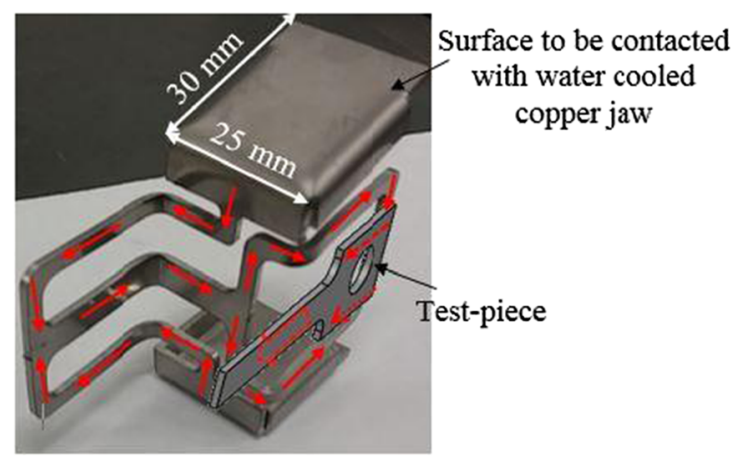

(d)

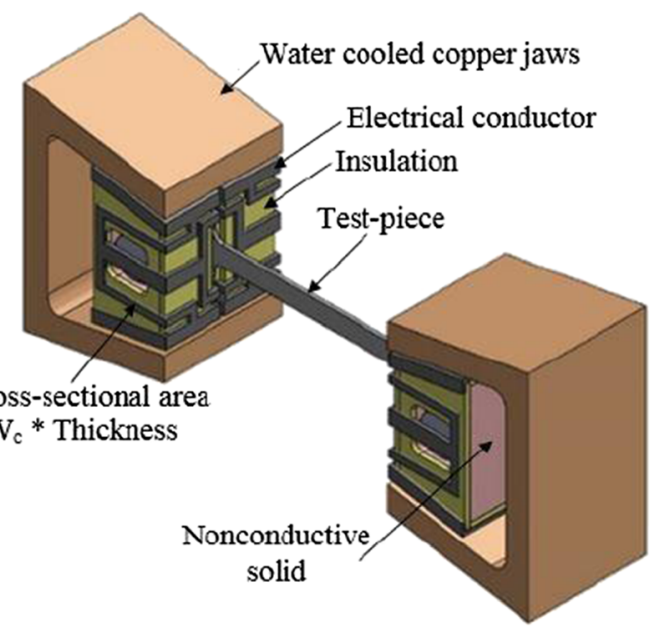

Fig. 3 New grip design (a) Principle of new grip design; (b) 2-dimensional electrical resistance conductor laser-cut from a plate, with schematic illustration of directions of current flow ('Ac'Cross-sectional area of arm and 'Wc' width of arm); and (c) Electrical resistance conductor folded into 3-dimension, with schematic illustration of current flow from the grips (d) CAD design of the assembly of new grip design

copper jaw and also part of excess heat can be transferred to the test-piece grip section.

\section{Refinements to Reduce the Heat Loss}

Heat loss from the test-piece is reduced by replacing the conventional solid metallic grips with a nonconductive material. Also a thermally insulating sheet is used to cover the electrically and thermally insulating blocks to reduce heat transfer from the test-piece to grips and then to the water cooled jaws. The electrical resistance conductor top surface is in contact with water cooled copper jaws is shown in Fig. 3(c). The electrical current supplied from an AC power source in the Gleeble passes through the copper jaws, the self-heating network wrapped around the grips and into the test-piece. The nonconductive grips are used to hold the test-piece during a test, one bolt and nut for each pair of grips was used to rigidly attach and align the test-piece. Whereas, in the conventional set-up, the current passes from the water-cooled copper jaws through the metal grips, resulting in significant heat loss from test-piece to jaws.

The electrical network can be made from conductive material (such as stainless steel, copper, etc.) through laser cutting from a sheet plate, and bent to the required configuration. As shown in Fig. 3(b) and (c), an electrical current passes to the test-piece only through the conducting network that becomes hot because of its high resistivity. The essence of the proposed concept is the design of network resistance, which depends on both resistivity of the material and geometry as defined in equation (2).

Electrical conductor resistance $=\frac{\rho_{c^{*} L_{c}}}{A_{c}}$

Where ' $\rho_{c}$ ' is electrical conductor resistivity, ' $L_{c}$ ' is the effective length of the network and ' $A_{c}$ ' is its crosssectional area. The length of the network was kept as long as possible within the working space, so design variables were the type of material and cross-sectional area only. To understand the effect of the type of electrical conductor material and cross-sectional areas on thermal gradient, coupled Thermal-Electric Finite element simulation was carried out using ABAQUS/ Standard, which is explained in the next section. The assembly of the proposed design is shown in Fig. 3(d). 


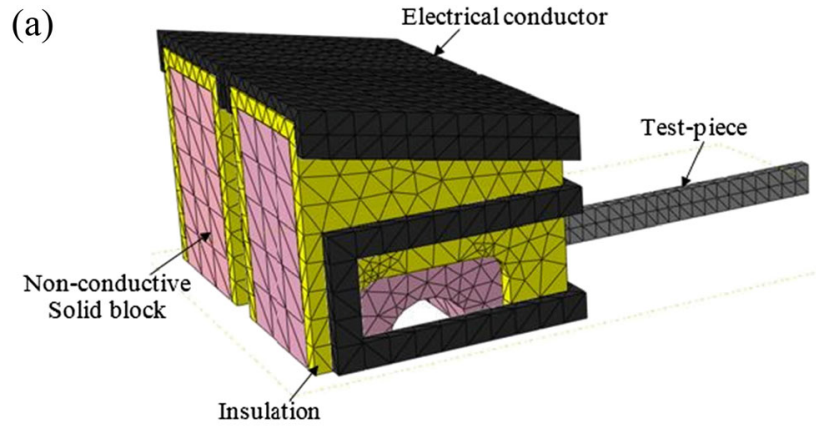

(b)

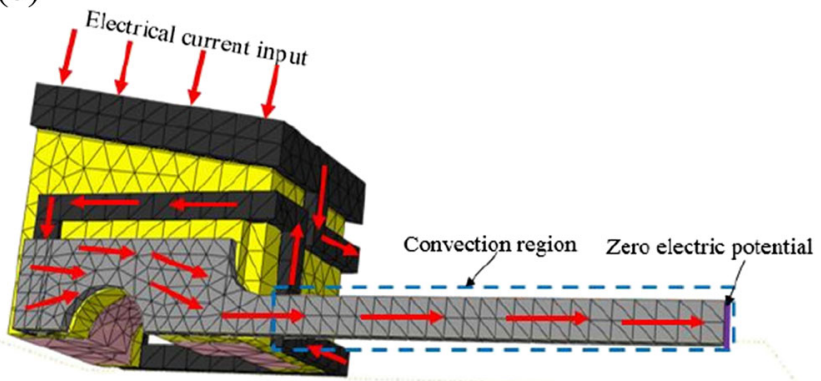

Fig. 4 Thermal-Electric Finite element model (a) FE model for a quarter of the Gleeble test set-up; and (b) Boundary conditions in FE model

\section{Finite Element Modeling}

To refine the proposed grip design, Finite element modelling of coupled Thermal-Electric analysis was simulated using ABAQUS/Standard along with user defined temperature feedback control subroutine called 'UAMP'. Coupled thermalelectric finite element simulation was conducted for heating, soaking and cooling of the steel test-piece at specific rates. The Finite element model is shown in Fig. 4(a). Due to the symmetric feature of the design and current flow, only a quarter of the set-up is simulated. The boundary conditions considered for the thermal-electric simulation are shown in Fig. 4(b). The electric current was input at one end of the grips and the mid length of the test-piece was specified as having zero electric current potential. Heat loss from the test-piece to the grips by conduction and to the atmosphere by convection $(h=$ $20 \mathrm{~W} / \mathrm{m}^{2}-K$ ) were considered in the simulation. The testpiece was in perfect contact with insulation at the interface and hence the interfacial heat transfer co-efficient was not considered; also, the contact heat transfer coefficient at the interface of test-piece and grips has little effect on the uniform zone [24]. The test-piece geometry used in this study is shown in Fig. 6(a). Test-piece geometry was selected to keep the longest jaw separations within existing Gleeble stroke and also to maintain minimum possible surface contact area with the nonconductive solid block.

Temperature dependent thermal properties considered in the simulation are listed in Tables 1 and 2. Carbon steel and stainless steel properties, used for the electrical network were obtained from relationship given in Appendix 2. The given relationship is valid for all types of carbon steels irrespective of steel phases [27]. Defining the electrical conductivity and density as a function of temperature does not have a significant effect on the predicted temperature fields [30] and hence they are kept constant as given in Table 3. The test-piece and grips were discretized with 4-node linear coupled thermalelectrical tetrahedron (DC3D4E) elements to capture the thermal and mechanical gradients in the gauge section.

Control of the temperature profile as shown in Fig. 6(b), performed in real tests by the thermocouple fixed at the testpiece centre, through controlling the amplitude of input current, was simulated through the user-defined subroutine, UAMP. The temperature difference between the prescribed and simulated temperature profiles at the middle of the testpiece for every time increment were calculated during the simulation as in eq. (3), and input current was varied according to eq. (4) and (5). Detailed information about UAMP along with Abaqus/standard is given in [11, 30].

$$
\Delta T_{\mathrm{i}}=T_{i}^{p}-T_{i}^{S}
$$

$$
\Delta I=\left(1+\frac{\Delta T_{i}}{T_{i}^{p}}\right)^{\alpha} \pm \beta
$$

Table 1 Thermal conductivity of different materials at various temperatures obtained from the literatures [27-29]

\begin{tabular}{lllll}
\hline $\begin{array}{l}\text { Temperature } \\
{ }^{\circ} \mathrm{C}\end{array}$ & $\begin{array}{l}\text { Steel } \\
(\mathrm{W} / \mathrm{m}-\mathrm{K}) \\
{[27]}\end{array}$ & $\begin{array}{l}\text { Stainless } \\
\text { steel } \\
(\mathrm{W} / \mathrm{m}-\mathrm{K}) .\end{array}$ & $\begin{array}{l}\text { Copper } \\
(\mathrm{W} / \mathrm{m}-\mathrm{K})\end{array}$ & $\begin{array}{l}\text { Calcium-Magnesium Silicate Thermal insulation } \\
\text { [27] }\end{array}$ \\
\hline 20 & 53.334 & 14.854 & 400.68 & 0.04 \\
200 & 47.34 & 17.14 & 388.35 & 0.04 \\
400 & 40.68 & 19.68 & 374.65 & 0.07 \\
600 & 34.02 & 22.22 & 360.96 & 0.10 \\
800 & 27.36 & 24.76 & 347.26 & 0.14 \\
1000 & 27.36 & 27.3 & 335.13 & 0.19 \\
1200 & 27.36 & 29.84 & 331.71 & 0.25 \\
\hline
\end{tabular}


Table 2 Specific heat of different materials at various temperatures obtained from the literatures [27-29]

\begin{tabular}{lllll}
\hline $\begin{array}{l}\text { Temperature } \\
{ }^{\circ} \mathrm{C}\end{array}$ & $\begin{array}{l}\text { Steel }(\mathrm{J} / \mathrm{kg}- \\
\mathrm{K})[27]\end{array}$ & $\begin{array}{l}\text { Stainless } \\
\text { steel } \\
(\mathrm{J} / \mathrm{kg}-\mathrm{K}) \\
{[27]}\end{array}$ & $\begin{array}{l}\text { Copper } \\
(\mathrm{J} / \mathrm{kg}-\mathrm{K}) \\
{[28]}\end{array}$ & $\begin{array}{l}\text { Calcium-Magnesium Silicate Thermal insulation } \\
\text { material }(\mathrm{J} / \mathrm{kg}-\mathrm{K})[29]\end{array}$ \\
\hline 20 & 440 & 460 & 380 & 750 \\
200 & 530 & 500 & 410 & 750 \\
400 & 606 & 520 & 420 & 750 \\
600 & 760 & 540 & 440 & 750 \\
800 & 803 & 560 & 460 & 750 \\
1000 & 650 & 570 & 490 & 750 \\
1200 & 1200 & 600 & 510 & 750 \\
\hline
\end{tabular}

$I_{i}=I_{i-1} * \Delta I$

$T_{i}^{p}$ and $T_{i}^{s}$ are the prescribed and simulated temperatures at each time increment, $\alpha$ is a coefficient that remains constant according to the corresponding time interval as shown in Table 4, which was defined by iteration until the simulated temperature profile matched the required heating cycle and calibrated with experimental temperature profile as shown Fig. 6(b). $\beta$ is a constant coefficient, and its value is 0.001 . The correction term, $\Delta I$, is then multiplied by the current used $\left(I_{i-1}\right)$ in the previous time increment.

Finite element simulation was performed with three different electrical conductor materials namely, stainless steel, copper and carbon steel, all of which have different electrical and thermal properties. For each material, three cross-sectional areas were considered. Due to available working space and feasibility, only thickness of the conductor was varied while the width was kept constant at $3 \mathrm{~mm}$ as shown in Fig. 3(b). Three different crosssectional areas were $3 \mathrm{~mm}^{2}, 4.5 \mathrm{~mm}^{2}$ and $6 \mathrm{~mm}^{2}$, which were achieved by only changing the thickness of the network arms to $1 \mathrm{~mm}, 1.5 \mathrm{~mm}$ and $2 \mathrm{~mm}$ respectively.

\section{Experimental Detailsb}

\section{Experimental Setup}

The electrically non-conducting blocks were made of mica electrical insulating film, and the insulating layer of calcium magnesium silicate. The electrical network shown in Fig. 2(c) was made of stainless steel with a cross-sectional area of $4.5 \mathrm{~mm}^{2}$, which was chosen with the help of finite element simulation. The complete experimental setup and test-piece at austenization temperature, is shown in Fig. 5(a) and (b). It is noted that the experimental assembly is slightly different from the CAD model as shown in Fig. 3(d), since the middle segment of electrical networks of both sides were bent to opposite direction, to avoid interference with the screws. Because the electrical networks are not the part to ensure the integrity of the grips and to provide clamping force, the influence of this difference is negligible. Two flat-head nozzles were connected to the cooling system to perform air cooling at the front and the back sides of the test-piece to provide uniform cooling through the gauge region. In order to compare the temperature field and deformation behaviour, the thermo-mechanical experiment was also performed with conventional grips.
Table 3 Material properties at room temperature

\begin{tabular}{lrlll}
\hline Physical properties & Steel & $\begin{array}{l}\text { Stainless } \\
\text { steel }\end{array}$ & Copper & $\begin{array}{l}\text { Calcium-Magnesium Silicate Thermal } \\
\text { insulation material }\end{array}$ \\
\hline $\begin{array}{l}\text { Density }\left(\mathrm{kg} / \mathrm{m}^{3}\right) \\
\begin{array}{l}\text { Electrical conductivity } \\
(\Omega-\mathrm{m})^{-1}\end{array}\end{array}$ & $\begin{array}{r}6.29 * \\
10^{6}\end{array}$ & $1.45 * 10^{6}$ & $\begin{array}{r}59.6^{*} \\
10^{6}\end{array}$ & $1 * 10^{-4}$ \\
\hline
\end{tabular}

Table 4 Coefficient $\alpha$ used in the UAMP subroutine to achieve the replication of the prescribed heating cycle

\begin{tabular}{llllll}
\hline $\begin{array}{l}\text { Process } \\
\text { stage }\end{array}$ & $\begin{array}{l}\text { Heating from } 20^{\circ} \mathrm{C} \\
\text { to } 750{ }^{\circ} \mathrm{C} \text { at } 9{ }^{\circ} \mathrm{C} / \mathrm{s}\end{array}$ & $\begin{array}{l}\text { Heating from } 750{ }^{\circ} \mathrm{C} \\
\text { to } 900{ }^{\circ} \mathrm{C} \text { at } 3{ }^{\circ} \mathrm{C} / \mathrm{s}\end{array}$ & $\begin{array}{l}\text { Soaking at } \\
900{ }^{\circ} \mathrm{C}(45 \mathrm{~s})\end{array}$ & $\begin{array}{l}\text { Cooling to deformation } \\
\text { temperature at } 50{ }^{\circ} \mathrm{C} / \mathrm{s}\end{array}$ & $\begin{array}{l}\text { Testing at deformation } \\
\text { temperature }\end{array}$ \\
\hline $\begin{array}{l}\text { Coefficient } \\
(\alpha)\end{array}$ & 0.5 & 2.0 & 1.0 & 0.02 & 0.1 \\
\hline
\end{tabular}


(a)

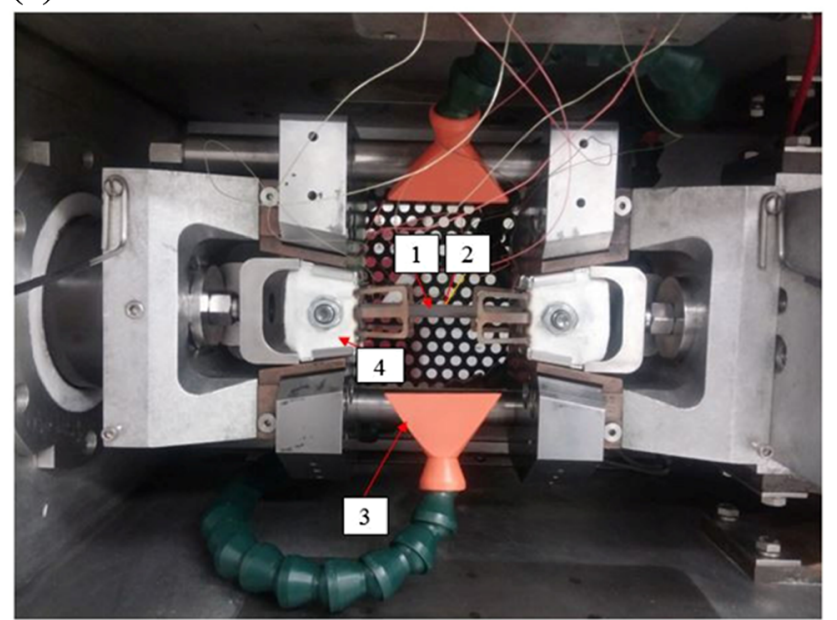

1- Test-piece; 2- Thermocouple; 3-Air cooling nozzle; 4- New grip

(b)

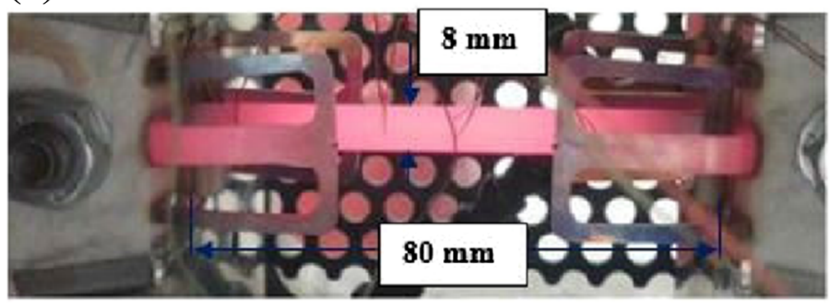

Fig. 5 set-up with new grip in the Gleeble 3800 (a) New grip experimental set-up along with air cooling nozzle; and (b) Test set-up with the test-piece heated up with a long high temperature span

\section{Experimental Procedure}

Zinc coated $22 \mathrm{MnB} 5$ boron steel, $1.5 \mathrm{~mm}$ thick, was used as test material for this study. The zinc coating was removed by sandblasting before heat treatment to prevent zinc contamination of the vacuum chamber at higher

(a)

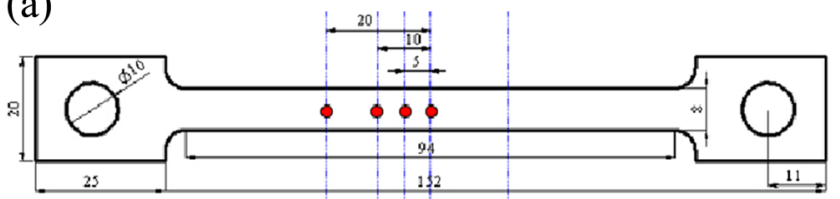

(b)

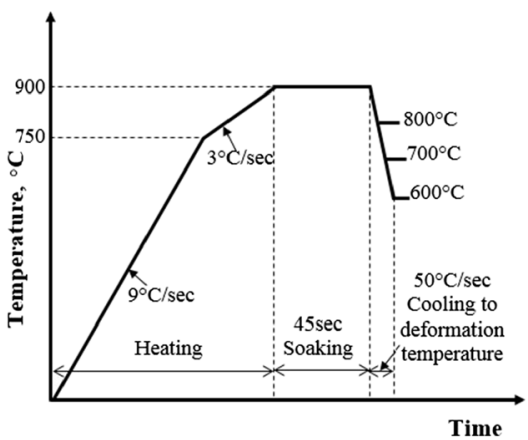

Fig. 6 (a) Actual test-piece geometry; and (b) Temperature profile

temperatures. During the test, the temperatures were recorded at four different positions along the specimen gauge length using the thermocouples TC1 (centre), TC2 ( $5 \mathrm{~mm}$ away from centre), TC3 (10 mm away from centre) and TC4 (20 mm away from centre) as shown in Fig. 6(a), and the thermocouple at the centre of the test-piece was used to monitor the temperature and send the feedback to the control system to maintain the required temperature profile. Temperature profile during heating, soaking, and cooling to deformation temperatures $800{ }^{\circ} \mathrm{C}, 700{ }^{\circ} \mathrm{C}$, and $600{ }^{\circ} \mathrm{C}$ is shown in Fig. 6(b). Digital images of the test piece were recorded during elongation with the Photron FASTCAM Mini UX50

(a)
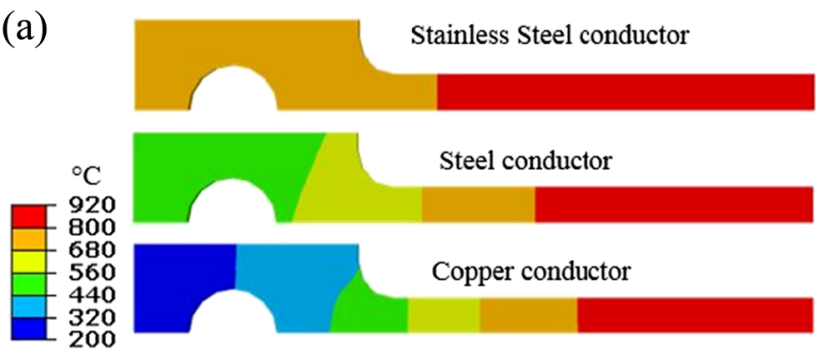

(b)
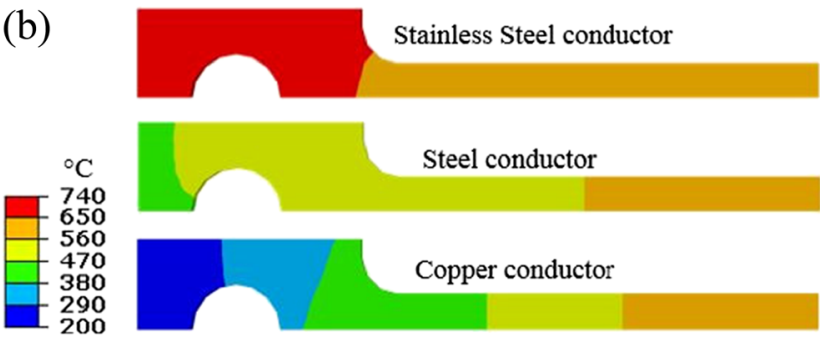

(c)

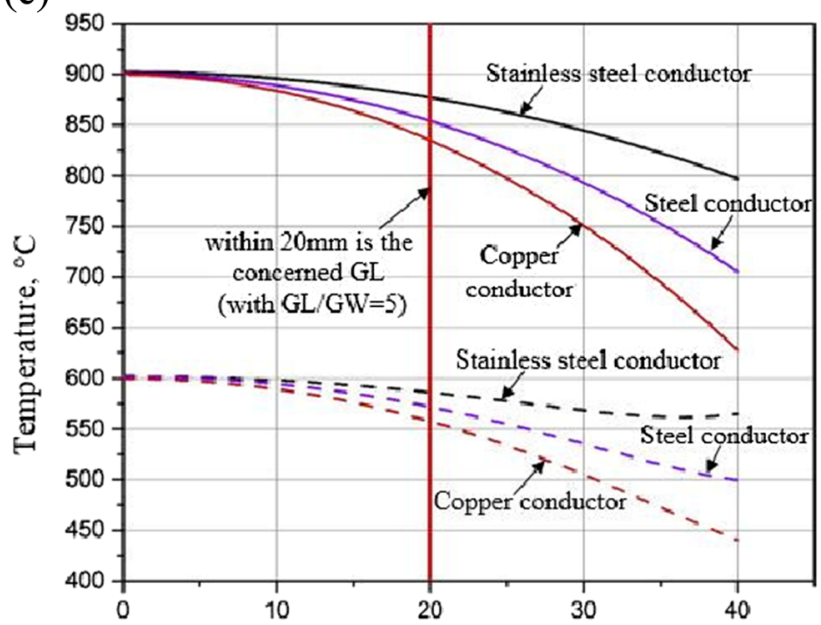

Distance from the middle of the test-piece, $\mathrm{mm}$

Fig. 7 Simulated temperature distributions in test-piece heated by using electrical conductor made of different materials with the same geometric design (cross-section area $=4.5 \mathrm{~mm}^{2}$ ) (a) Soaking at $900{ }^{\circ} \mathrm{C}$; (b) After rapid cooling to $600{ }^{\circ} \mathrm{C}$; and (c) Summary of temperature distribution curves 
Table 5 Simulated temperature deviation along test-piece during soaking at $900{ }^{\circ} \mathrm{C}\left(T_{\text {mid }}\right)$ with different electrical conductor materials in new test grips

Electrical conductor Temperature, $T_{G L / 2}$ material

Percentage of temperature

deviation $\frac{(\Delta T)_{G L}}{T_{\text {mid }}} * 100$

\section{$20 \mathrm{~mm}$ away from middle} of the test-piece (for $40 \mathrm{~mm}$

Effective gauge length) $\mathrm{T}_{40 \mathrm{~mm}}$

\author{
$40 \mathrm{~mm}$ away from middle \\ of the test-piece (for $80 \mathrm{~mm}$ \\ gauge length) $\mathrm{T}_{80 \mathrm{~mm}}$ \\ Within $40 \mathrm{~mm} \quad$ Within $80 \mathrm{~mm}$ \\ effective gauge length gauge length
}

\begin{tabular}{|c|c|c|c|c|c|}
\hline Copper & $835^{\circ} \mathrm{C}$ & $628^{\circ} \mathrm{C}$ & $7.0 \%$ & $30.0 \%$ & $\begin{array}{l}\text { Less than austenite } \\
\text { start temperature } \\
\left(723^{\circ} \mathrm{C}\right)\end{array}$ \\
\hline Carbon Steel & $854^{\circ} \mathrm{C}$ & $705^{\circ} \mathrm{C}$ & $5.0 \%$ & $21.0 \%$ & $\begin{array}{l}\text { Less than austenite } \\
\text { start temperature } \\
\left(723^{\circ} \mathrm{C}\right)\end{array}$ \\
\hline Stainless steel & $877^{\circ} \mathrm{C}$ & $797^{\circ} \mathrm{C}$ & $2.5 \%$ & $11.0 \%$ & $\begin{array}{l}\text { greater than austenite } \\
\text { start temperature } \\
\left(723^{\circ} \mathrm{C}\right)\end{array}$ \\
\hline
\end{tabular}

system with a large aperture lens (F2.8). This system uses high speed camera having $1280 \times 1024$ pixels, mounted on tripod and positioned such that the camera lens is parallel to the tensile test-piece. The cameras have a maximum frame rate of 2500 frames/s. In this work, all images and load-displacement data were captured at 500 frames/s for strain rate of $1 / \mathrm{s}$. Once testing was completed, strains were computed from series of images using MATLAB Image processing technique as explained in Appendix. 3. Two thin wires were welded onto the testpiece for tracking lengthwise displacement and for tracking of lateral displacement by the sample edge detection method. Jenner et al., proposed a similar strain measurement technique and validated for high temperature tensile testing of boron steel [31].

It should be noted that effective gauge length (40 $\mathrm{mm}$ ) is considered as per the test standards [32, 33]. The percentage of the temperature gradient reduced in new grips compared to the conventional grips is calculated using equations (6) and (7).

Temperature gradient $(\Delta T)_{G L}=T_{m i d}-T_{G L / 2}$
Complete test-piece

Where ' $(\Delta T)_{G L}$ ' is the temperature gradient with in specific gauge length; ' $(\Delta T)_{G L, \text { conv }}$ and $(\Delta T)_{G L, \text { new }}$ ' are temperature gradient within specific gauge length for conventional grips and new grips, respectively. ' $T_{\text {mid }}$ ' is the temperature at the middle of the test-piece, ' $T_{G L / 2}$ ' is temperature at $20 \mathrm{~mm}$ and $40 \mathrm{~mm}$ away from the middle of the test-piece for effective gauge length of $40 \mathrm{~mm}$ and gauge length of $80 \mathrm{~mm}$, respectively.

\section{Results and Discussion}

Finite element simulation was carried out to validate the proposed concept and based on the simulation results, a new grip arrangement as shown in Fig. 3 was fabricated to conduct the experiments. The results of both Finite element simulation and experiments are discussed in detail below.

Table 6 Simulated temperature deviation along test-piece at start of deformation after cooling to $600{ }^{\circ} \mathrm{C}\left(T_{\text {mid }}\right)$ with different electrical conductor materials in new test grips

\begin{tabular}{|c|c|c|c|c|}
\hline \multirow[t]{2}{*}{$\begin{array}{l}\text { Electrical conductor } \\
\text { material }\end{array}$} & \multicolumn{2}{|l|}{ Temperature, $T_{G L / 2}$} & \multicolumn{2}{|c|}{$\begin{array}{l}\text { Percentage of temperature } \\
\text { deviation } \frac{(\Delta T)_{G L}}{T_{\text {mid }}} * 100\end{array}$} \\
\hline & $\begin{array}{l}20 \mathrm{~mm} \text { away from } \\
\text { middle of the test-piece } \\
\text { (for } 40 \mathrm{~mm} \text { Effective } \\
\text { gauge length) }\end{array}$ & $\begin{array}{l}40 \mathrm{~mm} \text { away from } \\
\text { middle of the test- } \\
\text { piece (for } 80 \mathrm{~mm} \\
\text { gauge length) }\end{array}$ & $\begin{array}{l}\text { Within } 40 \mathrm{~mm} \\
\text { effective gauge } \\
\text { length }\end{array}$ & $\begin{array}{l}\text { Within } 80 \mathrm{~mm} \\
\text { gauge length }\end{array}$ \\
\hline Copper & $558^{\circ} \mathrm{C}$ & $440^{\circ} \mathrm{C}$ & $7.0 \%$ & $26.0 \%$ \\
\hline Carbon Steel & $572{ }^{\circ} \mathrm{C}$ & $500^{\circ} \mathrm{C}$ & $5.0 \%$ & $17.0 \%$ \\
\hline Stainless steel & $586^{\circ} \mathrm{C}$ & $565^{\circ} \mathrm{C}$ & $2.0 \%$ & $6.0 \%$ \\
\hline
\end{tabular}


(a)
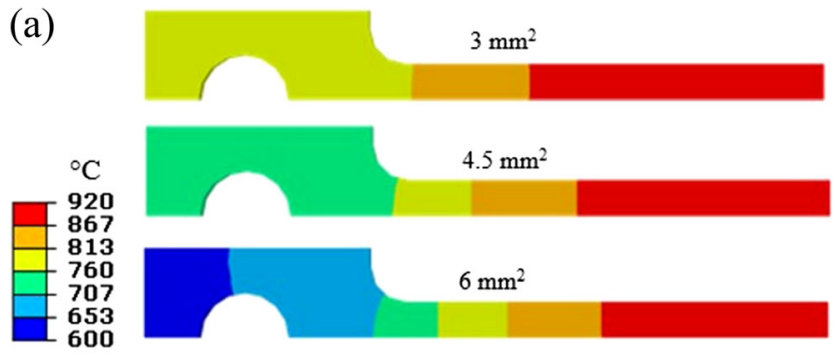

(b)

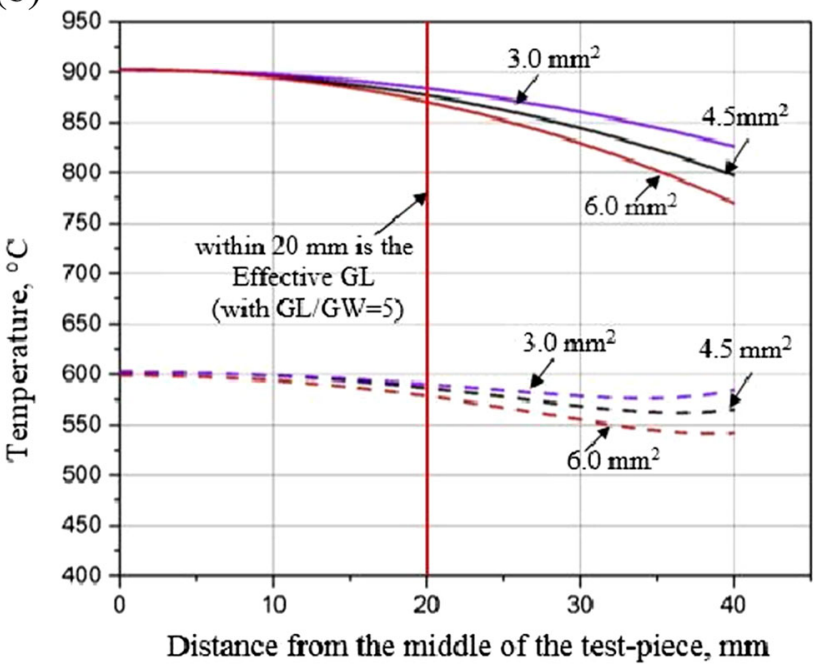

Fig. 8 Simulated temperature distributions in test-piece heated by various electrical conductor cross-sectional area with electrical conductors made of stainless steel material (a) Soaking at $900{ }^{\circ} \mathrm{C}$; and (b) Summary of temperature distribution curves

\section{Coupled Thermal-Electric Finite element analysis}

\section{Effect of electrical network material on temperature gradient}

The Finite element simulation was performed using electrical network branches with cross-sectional area of $4.5 \mathrm{~mm}^{2}$ and three different materials namely stainless steel, carbon steel and copper. The predicted temperature gradient along the gauge section during soaking at $900{ }^{\circ} \mathrm{C}$ is shown in Fig. 7(a) and at the start of deformation at $600^{\circ} \mathrm{C}$ is shown in Fig. 7(b).
While soaking within a gauge length of $80 \mathrm{~mm}$, the temperature gradient for an electrical conductor made of stainless steel, carbon steel and copper is $90{ }^{\circ} \mathrm{C}, 190{ }^{\circ} \mathrm{C}$ and $275{ }^{\circ} \mathrm{C}$ respectively. After cooling to $600{ }^{\circ} \mathrm{C}$ and at the onset of deformation, the temperature gradient in the test-piece is $25^{\circ} \mathrm{C}$, $105^{\circ} \mathrm{C}$ and $160^{\circ} \mathrm{C}$ for stainless steel, carbon steel and copper electrical conductors respectively. A summary of simulated temperature distribution during heating and after cooling is shown in Fig. 7(c). The temperature gradient for a stainless steel conductor is significantly less than that for the carbon steel and copper electrical conductors. This is because the electrical resistivity ' $\rho$ ' of stainless steel is approximately 4 times higher than that of carbon steel and approximately 30 times higher than that of copper. So more power is required to heat a test-piece and the temperature of the grips is higher. Using a stainless steel electrical conductor results in nearly uniform temperature within $40 \mathrm{~mm}$ effective gauge length. During soaking and deformation, the temperature deviation is only $2.5 \%$ and $2 \%$ respectively as listed in Tables 5 and 6 .

\section{Effect of electrical conductor cross-sectional area on temperature gradient}

The Finite element simulation was performed with electrical conductor made of stainless steel material and three different crosssectional areas namely $3 \mathrm{~mm}^{2}, 4.5 \mathrm{~mm}^{2}$ and $6 \mathrm{~mm}^{2}$. The predicted temperature contour during soaking with various cross-sectional areas is shown in Fig. 8(a). The summary of simulated temperature distribution during soaking and after cooling to deformation temperature is shown in Fig. 8(b). The lower the cross-sectional area, the better the uniformity in temperature which is due to the fact that the electrical resistance ' $R$ ' increases with decreasing crosssectional area ' $A_{c}$ ' and a higher grip temperature arises.

Table 7 shows that, $3 \mathrm{~mm}^{2}$ the electrical conductor temperature reaches nearly $1370{ }^{\circ} \mathrm{C}$ which is close to the melting point temperature of stainless steel $\left(1400^{\circ} \mathrm{C}\right)$. Therefore it is unsafe to use a very low cross-sectional area of $3 \mathrm{~mm}^{2}$. Electrical conductor with $4.5 \mathrm{~mm}^{2}$ cross-sectional area resulted in less thermal gradient (uniform temperature) and also it is

Table 7 Simulated temperature deviation along test-piece during soaking at $900{ }^{\circ} \mathrm{C}\left(T_{m i d}\right)$ with stainless steel electrical conductor materials and different cross-sectional areas in new test grips

\begin{tabular}{|c|c|c|c|c|c|}
\hline \multirow[t]{2}{*}{$\begin{array}{l}\text { Electrical } \\
\text { conductor cross- } \\
\text { sectional area }\end{array}$} & \multicolumn{2}{|l|}{ Temperature, $T_{G L / 2}$} & \multicolumn{2}{|c|}{$\begin{array}{l}\text { Percentage of temperature } \\
\text { deviation } \frac{(\Delta T)_{G L}}{T_{\text {mid }}} * 100\end{array}$} & \multirow[t]{2}{*}{$\begin{array}{l}\text { Maximum temperature } \\
\text { in electrical conductor } \\
\text { status }\end{array}$} \\
\hline & $\begin{array}{l}20 \mathrm{~mm} \text { away from middle } \\
\text { of the test-piece (for } 40 \mathrm{~mm} \\
\text { Effective gauge length) }\end{array}$ & $\begin{array}{l}40 \mathrm{~mm} \text { away from middle } \\
\text { of the test-piece (for } 80 \mathrm{~mm} \\
\text { gauge length) }\end{array}$ & $\begin{array}{l}\text { Within } 40 \mathrm{~mm} \\
\text { effective gauge } \\
\text { length }\end{array}$ & $\begin{array}{l}\text { Within } 80 \mathrm{~mm} \\
\text { gauge length }\end{array}$ & \\
\hline $3.0 \mathrm{~mm}^{2}$ & $886^{\circ} \mathrm{C}$ & $826^{\circ} \mathrm{C}$ & $2.0 \%$ & $8.0 \%$ & $1370^{\circ} \mathrm{C} /$ unsafe \\
\hline $4.5 \mathrm{~mm}^{2}$ & $877^{\circ} \mathrm{C}$ & $798^{\circ} \mathrm{C}$ & $2.5 \%$ & $11.0 \%$ & $900^{\circ} \mathrm{C} / \mathrm{safe}$ \\
\hline $6.0 \mathrm{~mm}^{2}$ & $870{ }^{\circ} \mathrm{C}$ & $770{ }^{\circ} \mathrm{C}$ & $3.3 \%$ & $14.0 \%$ & $680^{\circ} \mathrm{C} / \mathrm{safe}$ \\
\hline
\end{tabular}




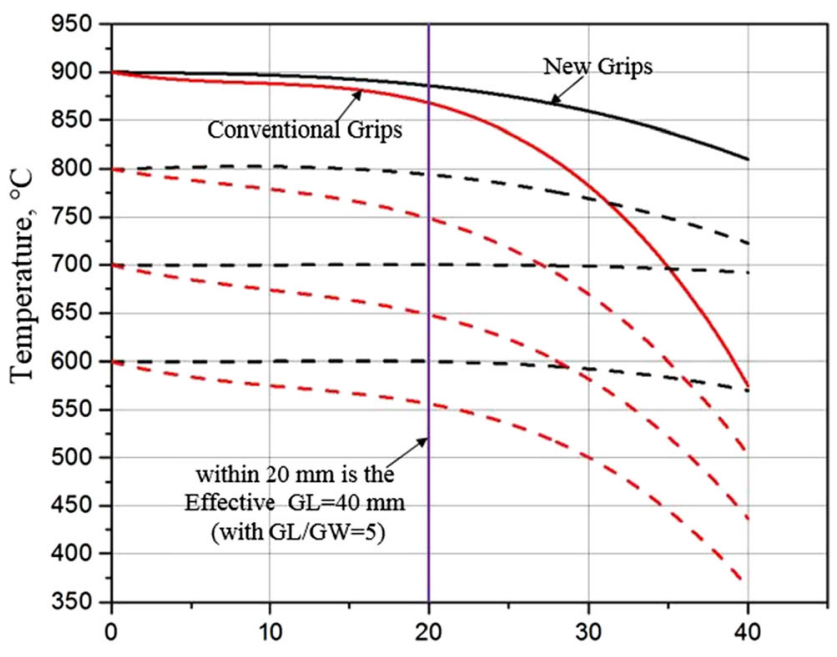

Distance from the middle of the test-piece, $\mathrm{mm}$

Fig. 9 Experimental temperature distribution at soaking (Solid line) and mechanical testing (dash line)

safe to use. The resultant temperature gradient was within $2.5 \%$ for $40 \mathrm{~mm}$ effective gauge length and within $11 \%$ for $80 \mathrm{~mm}$ gauge length.

From the Finite element simulation, it is evident that entire test-piece is above austenite start temperature $\left(723{ }^{\circ} \mathrm{C}\right)$ and also has uniform temperature within effective gauge length (40 $\mathrm{mm})$ which are impossible to achieve by using conventional grips.

\section{Experimental Results}

The experiment was carried out with both new and conventional grip arrangement. In this study, $80 \mathrm{~mm}$ parallel length was investigated. Fig. 9 shows that the temperature of the test-piece clamped by the new grips was greater than $800{ }^{\circ} \mathrm{C}$ along the whole measured gauge length of $80 \mathrm{~mm}$. The temperature gradient during soaking within $80 \mathrm{~mm}$ gauge length for conventional grips is $36 \%$, whereas for the new grips it is only $10 \%$ as shown in Table 8 . Table 9 shows experimentally measured temperature gradient for both new grips and conventional grips after rapid cooling to required deformation temperature. For $40 \mathrm{~mm}$ effective gauge length, temperature gradient reduced by $56.3 \%\left(32{ }^{\circ} \mathrm{C}\right.$ to $\left.14{ }^{\circ} \mathrm{C}\right)$ during soaking and reduced by $100 \%\left(\sim 50{ }^{\circ} \mathrm{C}\right.$ to zero temperature gradient) after rapid cooling to deformation temperature when compared to conventional grips.

Figure 10(a) shows the stress-strain curves obtained at designed deformation temperature of $900{ }^{\circ} \mathrm{C}$ and designed true strain rate of $1 / \mathrm{s}$ by using both conventional and new grips. Conventional grip resulted in large temperature gradient with localised deformation, thus resulted in a higher level of strain rate which leads in higher stress level due to visco plastic characteristics of boron steel at elevated temperature. Fig. 10(b) shows the local true strain, which was calculated according to the change of test-piece width at the corresponding section, along with the gauge region at various time intervals during deformation. Due to uniform temperature distribution within the $40 \mathrm{~mm}$ effective gauge region, the new grips resulted in homogeneous deformation before necking. On the other hand, for the conventional grips, the deformation is predominately concentrated at the middle of the test-piece. At the time interval of $0.40 \mathrm{~s}$, the deviation of true strain within the $40 \mathrm{~mm}$ effective gauge length reached to 0.43 for conventional grips; it is almost zero (0.02) when new grips employed. The percentage of strain gradient reduction is $95 \%$ when using the new grips over conventional grips as calculated using equations (8) and (9) which is summarised in Table 10 .

True strain gradeint $\Delta \varepsilon=\varepsilon_{\text {middle }}-\varepsilon_{20 \mathrm{~mm}}$

$\%$ of $\Delta \varepsilon$ reduction $=\frac{(\Delta \varepsilon)_{\text {std }}-(\Delta \varepsilon)_{\text {new }}}{(\Delta \varepsilon)_{\text {std }}}$

Where ' $\varepsilon_{\text {middle' }}$ is the local true strain at the middle of the test-piece and ' $\varepsilon_{20 \mathrm{~mm}}$ ' is the local true strain at $20 \mathrm{~mm}$ away from the middle of the test-piece for

Table 8 Measured temperature deviation along test-piece during soaking at $900{ }^{\circ} \mathrm{C}$ by using new and conventional test grips

\begin{tabular}{|c|c|c|c|c|c|}
\hline \multirow[t]{2}{*}{ Grips } & \multicolumn{2}{|l|}{ Temperature } & \multicolumn{2}{|c|}{$\begin{array}{l}\text { Percentage of temperature } \\
\text { deviation } \frac{(\Delta T)_{G L}}{T_{\text {mid }}} * 100\end{array}$} & \multirow[t]{2}{*}{ Complete test-piece } \\
\hline & $\begin{array}{l}20 \mathrm{~mm} \text { away from middle } \\
\text { of the test-piece (for } 40 \mathrm{~mm} \\
\text { Effective gauge length) }\end{array}$ & $\begin{array}{l}40 \mathrm{~mm} \text { away from middle } \\
\text { of the test-piece (for } \\
80 \mathrm{~mm} \text { gauge length) }\end{array}$ & $\begin{array}{l}\text { Within } 40 \mathrm{~mm} \\
\text { effective gauge length }\end{array}$ & $\begin{array}{l}\text { Within } 80 \mathrm{~mm} \\
\text { gauge length }\end{array}$ & \\
\hline New Grips & $886^{\circ} \mathrm{C}$ & $810^{\circ} \mathrm{C}$ & $1.5 \%$ & $10.0 \%$ & $\begin{array}{l}\text { greater than austenite start } \\
\text { temperature }\left(723^{\circ} \mathrm{C}\right)\end{array}$ \\
\hline $\begin{array}{l}\text { Conventional } \\
\text { Grips }\end{array}$ & $868^{\circ} \mathrm{C}$ & $574^{\circ} \mathrm{C}$ & $3.5 \%$ & $36.2 \%$ & $\begin{array}{l}\text { less than austenite start } \\
\text { temperature }\left(723^{\circ} \mathrm{C}\right)\end{array}$ \\
\hline
\end{tabular}


Table 9 Measured temperature deviation along test-piece at start of deformation by using new and conventional test grips

\begin{tabular}{|c|c|c|c|c|c|c|}
\hline \multirow[t]{2}{*}{$\begin{array}{l}\text { Deformation Temperature } \\
\text { at middle of the } \\
\text { test-piece }\left(T_{\text {mid }}\right)\end{array}$} & \multicolumn{2}{|l|}{$\begin{array}{l}\text { Conventional } \\
\text { Grips }\left(T_{G L / 2}\right)\end{array}$} & \multicolumn{2}{|l|}{$\begin{array}{l}\text { New Grips } \\
\left(T_{G L / 2}\right)\end{array}$} & \multicolumn{2}{|c|}{$\begin{array}{l}\text { Percentage of }(\Delta \mathrm{T})_{\mathrm{GL}} \\
\text { decrease in new grips } \\
\text { over conventional grips }\end{array}$} \\
\hline & $\begin{array}{l}20 \mathrm{~mm} \text { away from middle } \\
\text { of the test-piece (for } 40 \mathrm{~mm} \\
\text { Effective gauge length) }\end{array}$ & $\begin{array}{l}40 \mathrm{~mm} \text { away from } \\
\text { middle of the test- } \\
\text { piece (for } 80 \mathrm{~mm} \\
\text { gauge length }\end{array}$ & $\begin{array}{l}\text { Within } 40 \mathrm{~mm} \\
\text { effective gauge } \\
\text { length }\end{array}$ & $\begin{array}{l}\text { Within } 80 \mathrm{~mm} \\
\text { gauge length }\end{array}$ & $\begin{array}{l}\text { Within } 40 \mathrm{~mm} \\
\text { effective gauge } \\
\text { length }\end{array}$ & $\begin{array}{l}\text { Within } 80 \mathrm{~mm} \\
\text { gauge length }\end{array}$ \\
\hline $600^{\circ} \mathrm{C}$ & $556^{\circ} \mathrm{C}$ & $365^{\circ} \mathrm{C}$ & $600^{\circ} \mathrm{C}$ & $570{ }^{\circ} \mathrm{C}$ & $100.0 \%$ & $87.2 \%$ \\
\hline $700^{\circ} \mathrm{C}$ & $648^{\circ} \mathrm{C}$ & $436^{\circ} \mathrm{C}$ & $700^{\circ} \mathrm{C}$ & $692{ }^{\circ} \mathrm{C}$ & $100.0 \%$ & $97.0 \%$ \\
\hline $800^{\circ} \mathrm{C}$ & $748^{\circ} \mathrm{C}$ & $503{ }^{\circ} \mathrm{C}$ & $800^{\circ} \mathrm{C}$ & $723^{\circ} \mathrm{C}$ & $100.0 \%$ & $74.1 \%$ \\
\hline $900^{\circ} \mathrm{C}$ & $868^{\circ} \mathrm{C}$ & $575^{\circ} \mathrm{C}$ & $886^{\circ} \mathrm{C}$ & $810^{\circ} \mathrm{C}$ & $56.3 \%$ & $72.3 \%$ \\
\hline
\end{tabular}

(a)

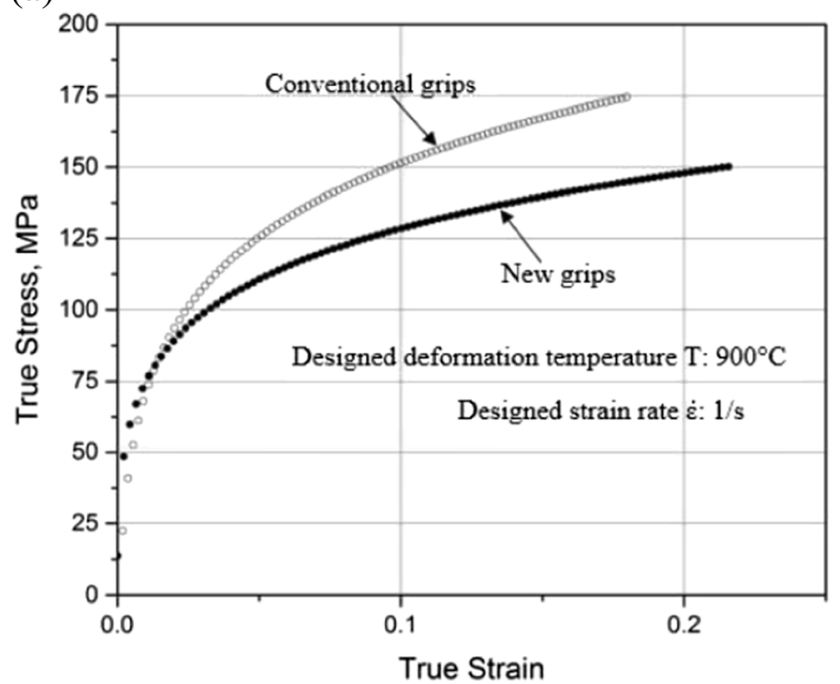

(b)

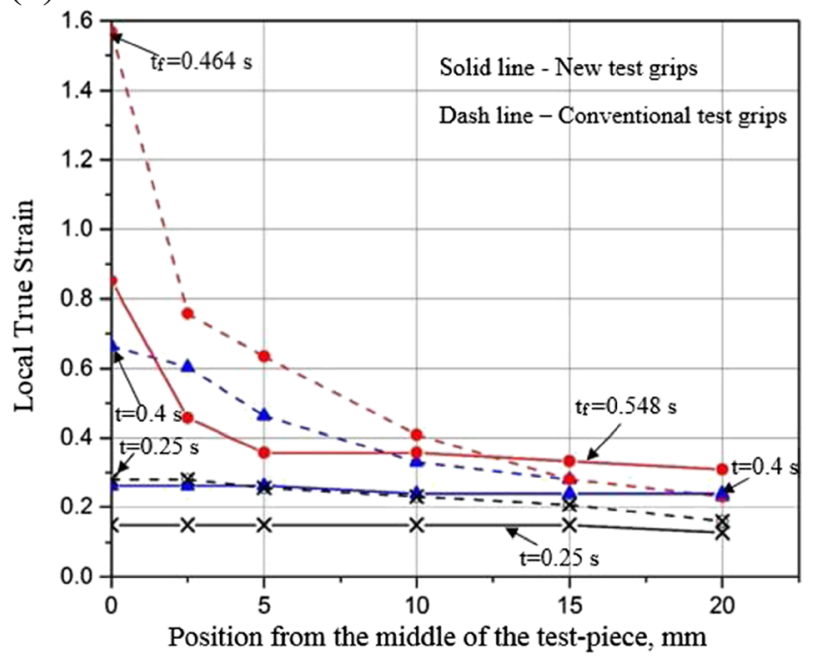

Fig. 10 Comparison of experimental results using the conventional and the new test grips (a) True stress-Strain curves: strain measured from effective Gauge length of $40 \mathrm{~mm}$ for tests using both sets of grips; and (b) Local true strain distribution along the effective gauge length of $40 \mathrm{~mm}$ at various time interval during deformation, for test results by using new test grips (Solid lines) and conventional test grips (Dash lines)
$40 \mathrm{~mm}$ effective gauge length. $(\Delta \varepsilon)_{\text {new }}$ and $(\Delta \varepsilon)_{\text {std }}$ are strain gradients in new and conventional grips respectively.

\section{Analytical Method for Design of Electrical Conductor}

To achieve fully austenitic microstructure throughout the testpiece and uniform temperature within the effective gauge region, an electrical conductor with appropriate material and cross-sectional area is required. In this study, design of the conductor was assisted by Finite element simulation to validate the new grip design. However finite element simulation is time consuming to design and choose the conductor material with respect to the test material type and its gauge section. Therefore an analytical relationship has been derived, relating test-piece and electrical conductor. This relationship can help choice of appropriate material with suitable cross-sectional area, for a given test material type and gauge section geometry. The equivalent electrical circuit diagram with real electrical conductor design is shown in Fig. 11(a) and (b).

Using Kirchhoff's law and assumptions made based on the Finite element simulation results, the relationship has been derived between the electrical conductor and test-piece which is detailed in Appendix. 1. The derived correlation is described in equation (10).

$$
\begin{aligned}
& \frac{\dot{T}_{C}}{\dot{T}_{S}}=\frac{\frac{I_{C 1}^{2} * \frac{\rho_{C}}{I_{S}^{2}}}{\rho_{S}}}{\left.\frac{A_{C}^{2}(\text { density })}{A_{S}^{2}} * \frac{C_{C}}{(\text { density })}\right)_{S}}=\frac{1}{C_{S}} * \frac{F}{G^{2 *} D^{*} H} \\
& \text { where } F=\frac{\rho_{C}}{\rho_{S}} ; G=\frac{A_{C}}{A_{S}} ; H=\frac{C_{C}}{C_{S}} \text { and } D=\frac{(\text { density })_{C}}{(\text { density })_{S}}=D \\
& 1.8^{*} \dot{T}_{S} \leq \dot{T}_{C} \leq 2 * \dot{T}_{S} ; 900^{\circ} \mathrm{C} \leq T_{C} \leq 1000^{\circ} \mathrm{C}
\end{aligned}
$$

Where ' $F$ ' is the resistivity ratio of electrical conductor to test-piece; ' $H$ ' is the ratio of specific heat of conductor to testpiece; ' $G$ ' is the ratio between cross-sectional area of electrical 
Table 10 Measured Local True Strain distribution along effective gauge length of $40 \mathrm{~mm}$ with new and conventional test grips

\begin{tabular}{llllll}
\hline Time interval (Seconds) & True Strain $(\varepsilon)$ & & $\begin{array}{l}\text { True Strain deviation } \\
\text { within } 40 \mathrm{~mm} \text { effective } \\
\text { gauge length }(\Delta \varepsilon)\end{array}$ & $\begin{array}{l}\text { Percentage of }(\Delta \varepsilon) \text { decrease } \\
\text { in new grips over } \\
\text { conventional grips }\end{array}$ \\
\cline { 2 - 5 } & $\begin{array}{l}\text { Conventional grips } \\
\varepsilon_{\text {middle }} \varepsilon_{20 m m}\end{array}$ & New grips $\varepsilon_{\text {middle }} / \varepsilon_{20}$ & & Conventional grips & New grips \\
\hline 0.25 & $0.28 / 0.16$ & $0.15 / 0.13$ & 0.12 & 0.02 & $82.0 \%$ \\
0.40 & $0.66 / 0.23$ & $0.26 / 0.24$ & 0.43 & 0.02 & $95.0 \%$ \\
Failure & $1.57 / 0.23$ & $0.85 / 0.31$ & 1.34 & 0.54 & $59.4 \%$ \\
\hline
\end{tabular}

conductor to test-piece; and ' $D$ ' is the ratio between density of electrical conductor to test-piece. Where $\rho_{C}, A c, C_{C}, D_{C}, T_{C}$ are resistivity, cross-sectional area, specific heat, density and temperature of the conductor, respectively, and $\rho_{S}, A_{S}, C_{S}$, $D_{S}, T_{S}$ are resistivity, cross-sectional area, specific heat, density and temperature of test-piece, respectively.

For the given test material and its parallel section, the selection of the material and the cross-sectional area needs to be based on equation (10) and must fulfil the heating rate condition given in equation (12) for a successful, and uniform temperature thermo-mechanical test. If the ratio of heating rate of electrical conductor $\left(\dot{T}_{C}\right)$ to the heating rate of test-piece $\left(\dot{T}_{S}\right)$ is greater than 2 , then the electrical conductor will reach its melting point due to overheating as discussed in appendix. 1 .

If the test material is changed from steel to aluminium, it is strongly recommended to avoid stainless steel electrical conductor. Electrical resistivity of stainless steel is approximately 25 times higher than the aluminium, which will increase the

(a)

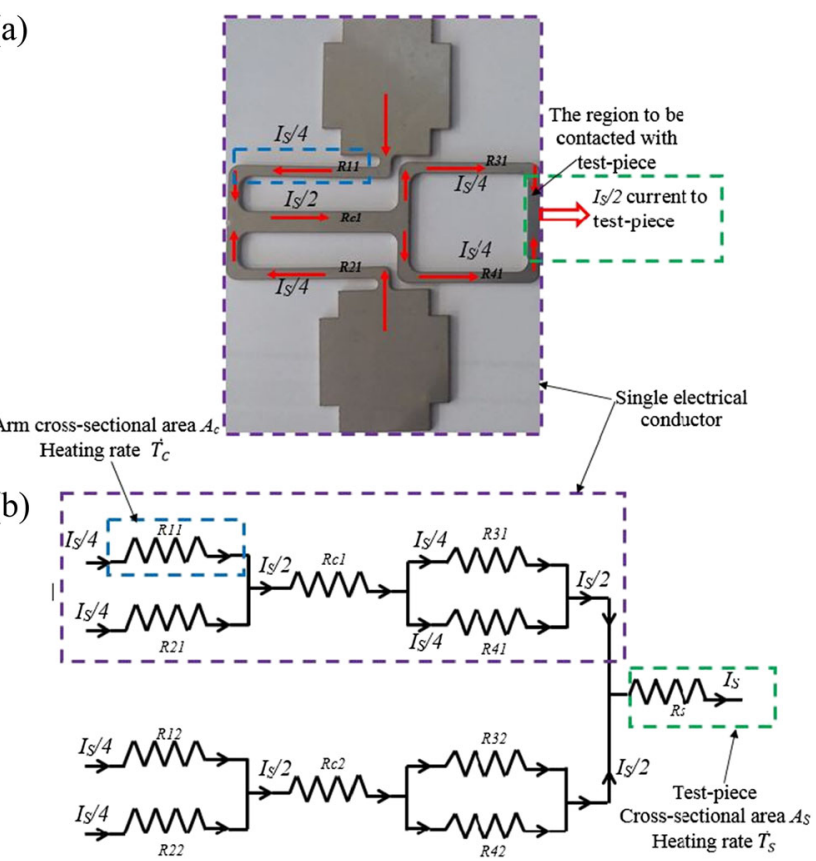

Fig. 11 Electrical resistance conductor design (a) Single electrical conductor; and (b) Pair of electrical conductor equivalent circuit diagram ratio of heating rate of coonductor to test-piece by 10 . This will result in overheating of electrical conductor before reaching the test-piece soaking temperature, subsequently may result in electrical current cut off during the test., Hence use of electrical conductor made with steel or copper material is recommended for aluminium test material.

\section{Conclusions}

Based on Finite element simulation, a new design of grip was fabricated for Gleeble uniaxial thermo-mechanical testing. The design was practically tested using boron steel testpieces for test in which test-pieces were heated to the austenite range and then air cooled to deformation temperature and the results were compared with those obtained using conventional grips. An analytical method was developed as an effective tool to determine grip design parameters. From this work the following conclusions have been drawn:

- The new grip design for achieving less temperature gradient and uniform temperature within effective gauge section $\left(\frac{\text { length }}{\text { width }}=5\right.$ ) was proven by both through ABAQUS/ Standard coupled Thermal-Electric simulation and experiments on a Gleeble Materials-Simulator.

- Using the new grips a temperature to above austenitic start $\left(723{ }^{\circ} \mathrm{C}\right)$ along the test-piece length during soaking at $900{ }^{\circ} \mathrm{C}$, was achieved. The temperature gradient for $80 \mathrm{~mm}$ gauge length of test-piece reduced from $325^{\circ} \mathrm{C}$ to $90{ }^{\circ} \mathrm{C}$ during soaking and reduced from $264{ }^{\circ} \mathrm{C}$ to $8{ }^{\circ} \mathrm{C}$ after rapid cooling to deformation temperature of $700{ }^{\circ} \mathrm{C}$, which is $72 \%$ and $97 \%$ less than the temperature gradient arising using conventional grips during soaking and after cooling respectively.

- When the new grips were used for $40 \mathrm{~mm}$ effective gauge length, the temperature gradient was reduced by $56 \%$ $\left(32{ }^{\circ} \mathrm{C}\right.$ to $14{ }^{\circ} \mathrm{C}$ ) during soaking and reduced by $100 \%$ ( $\Delta \mathrm{T}$ is $52{ }^{\circ} \mathrm{C}$ to zero) immediately after rapid cooling to $700{ }^{\circ} \mathrm{C}$ compared with that for conventional grips.

- As tested at $900{ }^{\circ} \mathrm{C}$, elimination of temperature gradient by using the new grips also resulted in much more homogeneous deformation, with strain gradient reduced by $95 \%$ 
within the $40 \mathrm{~mm}$ effective gauge length compared with conventional grips.

- An analytical correlation between the electrical conductor design and test-piece has been derived, which can be used for selecting appropriate material and geometrical dimensions, for a given test material and test-piece design without performing detailed Finite element simulation.

The innovative design of the new grips developed in this study enables uniaxial tensile testing under hot stamping conditions to be performed in a simpler way resulting in more accurate results than obtainable from existing test methods. The concept of self-resistance heating grips, which ensures better uniformity of temperature fields in test-pieces, can also be applied for tests under complex tension conditions, such as biaxial tensile.

Acknowledgements The authors would like to thank Tata Steel for financial support provided for this project. Authors also likes to acknowledge Dr. Arunansu Haldar, Dr. Theo Kop, Dr. Peter van Liempt and Mr. Nico Langerak of Tata Steel for their valuable suggestions.

\section{Appendix-1}

Figure 11 Shows the equivalent electrical conductor and test-piece circuit diagram, the heat generation and increase in temperature in both test-piece and electrical conductor is calculated as below.

Assume, rate of cooling is ignored in both electrical conductor and test-piece.

Electrical power dissipation $P=I^{2} * R(T)$

Electrical energy $E(t)=\int P d t$

Temperature $T=T 0+d T$

Change in Temperature $d T=\frac{E(t)}{m * C}$

Where ' $P$ ' is power; ' $I$ ' is electrical current; ' $R(T)$ ' Resistance depends on Temperature; ' $E(t)$ ' is Electrical energy; ' $m$ ' is mass; and ' $C$ ' is specific heat.

$m=V *$ density

$V=l * A$

Where ' $V$ ' is volume; ' $l$ ' is length; and ' $A$ 'is area

Resistance $R(T)=\frac{l}{A} * \rho(T)$

$\rho(T)=\rho+T * \alpha$
Where ' $\rho(T)$ 'is resistivity depends on the temperature; and ' $\alpha$ ' is thermal coefficient.

$R(T)=\frac{l}{A} *(\rho+T * \alpha)$

$R(d T)=\frac{l}{A} *\left(\rho_{0}+d T * \alpha\right)$

Where ' $\rho_{0}$ ' is resistivity at room temperature

Electrical energy $E(t)=m * C * d T$

Substitute all the values in equation 16

$d T=\frac{1}{m * C} \int I^{2} * R(d T) d t$

$d T=\frac{I^{2}}{m * C} \int \frac{l}{A} *\left(\rho_{0}+T * \alpha\right) d t$

$d T=\frac{I^{2}}{\text { length } * A * \text { density } * C} \int \frac{l}{A} *\left(\rho_{0}+d T * \alpha\right) d t$

$d T=\frac{I^{2}}{A^{2} * \text { density } * C} \int\left(\rho_{0}+d T * \alpha\right) d t$

if $d T * \alpha \ll \rho_{0}$ then $d T=\frac{I^{2} * \rho_{0} * d t}{A^{2} * \text { density } * C}$

$\dot{T}=\frac{d T}{d t}=\frac{I^{2} * \rho_{0}}{A^{2} * \text { density } * C}$

Where ' $\dot{T}$ ' is rate of heating

$\dot{T}_{C}=\frac{I_{C 1}^{2} * \rho_{C}}{A_{C}^{2} *(\text { density })_{C} * C_{C}}$

$\dot{T}_{S}=\frac{I_{S}^{2} * \rho_{S}}{A_{S}^{2} *(\text { density })_{S} * C_{S}}$

Where subscripts ' $C$ ' and ' $S$ ' denote the electrical conductor and test-piece respectively

$\frac{\dot{T}_{C}}{\dot{T}_{S}}=\frac{\frac{I_{C 1}^{2}}{I_{S}^{2}} * \frac{\rho_{C}}{\rho_{S}}}{\frac{A_{C}^{2}}{A_{S}^{2}} * \frac{(\text { density })_{C}}{(\text { density })_{S}} * \frac{C_{C}}{C_{S}}}$

Current flow in one conductor is ' $I_{C 1}$ '

$I_{C 1}=\frac{I_{S}}{4}$

Substitute in equation (30)

$\frac{\dot{T}}{\dot{T}}=\frac{\frac{1}{16} * \frac{\rho_{C}}{\rho_{S}}}{\frac{A_{C}^{2}}{A_{S}^{2}} * \frac{(\text { density })_{C}}{(\text { density })_{S}} * \frac{C_{C}}{C_{S}}}$ 
Assume $\frac{\rho_{C}}{\rho_{S}}=F ; \frac{A_{C}}{A_{S}}=G ; \frac{C_{C}}{C_{S}}=H$ and $\frac{(\text { density })_{C}}{(\text { density })_{S}}=D$

Then equation (31) becomes

$\frac{\dot{T}_{C}}{\dot{T}_{S}}=\frac{1}{16} * \frac{F}{G^{2} * D * H}$

In this case test-piece is steel and electrical conductor material is stainless steel substitute all the values at room temperature.

$$
\begin{gathered}
F=\frac{\rho_{C}}{\rho_{S}}=4.33 ; \\
G=\frac{A_{C}}{A_{S}}=\frac{4.5}{12}=0.375 \\
D=\frac{(\text { density })_{C}}{(\text { density })_{S}}=1 \\
H=\frac{C_{C}}{C_{S}}=1.045 \\
\frac{4.33}{\dot{T}_{C}}=\frac{1}{16} * \frac{4.375)^{2} * 1 * 1.045}{(0.84}=1.84 \\
\dot{T}_{C}=1.84 * \dot{T}_{S}
\end{gathered}
$$

The above relation shows that stainless steel electrical conductor heating rate is approximately double the test-piece heating rate.

$$
\left(\frac{d T}{d t}\right)_{C}=1.84 *\left(\frac{d T}{d t}\right)_{S}
$$

For the same increment ' $d t$ ' temperature increase in electrical conductor is $d T_{C}=1.84^{*} d T_{S}$

$$
\begin{aligned}
& \left(T_{0}-T_{C}\right)=1.84 *\left(T_{0}-T_{S}\right) \\
& T_{C}=\left(1.84 * T_{S}-0.84 * T_{0}\right)
\end{aligned}
$$

Where ' $T_{S}$ ' is test-piece soaking temperature and ' $T_{0}$ ' is room temperature typically $20^{\circ} \mathrm{C}$.

From the above equation (39), electrical conductor temperature $T_{C}=1639.2^{\circ} \mathrm{C}$; but in actual case in both experiment and simulation is $900{ }^{\circ} \mathrm{C}$ as shown in Table 7. The difference between actual and analytically calculated is due to rate of cooling to water cooled copper jaws, which is not considered in analytical calculation.

To find the fraction of cooling, let us introduce an effective heating factor ' $\mathrm{f}$ ' in the above equation

$T_{C}=\left(1.84 * T_{S}-0.84 * T_{0}\right) * f$

Effective heating factor ' $f$ ' calculated by inverse method from actual measured electrical conductor temperature. Then equation (40) becomes

$$
\begin{aligned}
900^{\circ} \mathrm{C} & =\left(1.84 * T_{S}-0.84 * T_{0}\right) * f \\
f & =0.55 \text { for } 4.5 \mathrm{~mm}^{2} \text { of stainless steel conductor } \\
f & =0.37 \text { for } 3 \mathrm{~mm}^{2} \text { of stainless steel conductor }
\end{aligned}
$$

Decrease of ' $f$ ' with increasing conductor temperature is denotes that, rate of cooling increases with increase in temperature of electrical conductor, so it was decided to keep safe temperature range, which will be safe for most of the condition.

$1.8 * \dot{\mathrm{T}}_{\mathrm{S}} \leq \dot{\mathrm{T}}_{\mathrm{C}} \leq 2 * \dot{\mathrm{T}}_{\mathrm{S}}$ so that conductor temperature $900^{\circ} \mathrm{C} \leq \mathrm{T}_{\mathrm{C}} \leq 1000^{\circ} \mathrm{C}$

The selection of the material and the cross-sectional area for electrical conductor with respect to the test-piece material and gauge section based on equation (33) must comply with the above heating rate correlation [equation (42)] for the successful and uniform temperature profile. Considering the heat loss to water cooled jaw, heating rate of conductor equal to 2 times of test-piece will be safer and should not be more than double.

\section{Appendix-2 [27]}

The specific heat of stainless steel $\mathrm{C}_{\mathrm{p}}[\mathrm{in} \mathrm{J} / \mathrm{Kg}-\mathrm{K}]$

$$
C p=450+0.28 * T-2.91 * 10^{-4} * T^{2}+1.34 * 10^{-7} * T^{3}
$$

The thermal conductivity of stainless steel $\mathrm{K}$ [in W/m-K]

$$
\mathrm{K}=14.6+1.27 * 10^{-2} * \mathrm{~T}
$$

The specific heat of carbon steel $\mathrm{C}_{\mathrm{p}}[$ in $\mathrm{J} / \mathrm{Kg}-\mathrm{K}]$

$$
\begin{aligned}
\mathrm{Cp} & =425+7.73 * 10^{-1} * \mathrm{~T}-1.69 * 10^{-3} * \mathrm{~T}^{2} \\
& +2.22 * 10^{-6} * \mathrm{~T}^{3} \text { for } 20 \mathrm{C} \leq \mathrm{T}<600^{\circ} \mathrm{C} \\
\mathrm{Cp} & =666+\frac{13002}{738-\mathrm{T}} \text { for } 600^{\circ} \mathrm{C} \leq \mathrm{T}<735^{\circ} \mathrm{C} \\
\mathrm{Cp} & =545+\frac{17820}{\mathrm{~T}-731} \text { for } 735^{\circ} \mathrm{C} \leq \mathrm{T}<900^{\circ} \mathrm{C}
\end{aligned}
$$

The thermal conductivity of carbon steel $K$ [in $\mathrm{W} / \mathrm{m}-\mathrm{K}$ ]

$\mathrm{K}=54-3.33 * 10^{-2} * \mathrm{~T}$ for $20^{\circ} \mathrm{C} \leq \mathrm{T}<800^{\circ} \mathrm{C}$

$\mathrm{K}=27.3$ for $800^{\circ} \mathrm{C} \leq \mathrm{T}<1200^{\circ} \mathrm{C}$ 


\section{Appendix-3}

Fig. 12 (a) Image processing technique in MATLAB for strain measurement; and (b) Flow chart to explain MATLAB image processing algorithm for strain measurement (a)

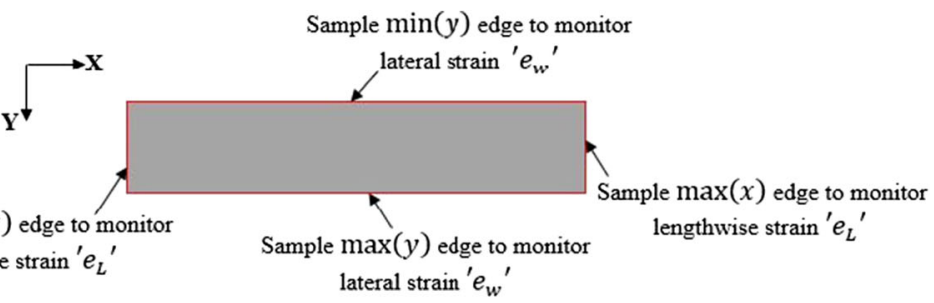

(b)

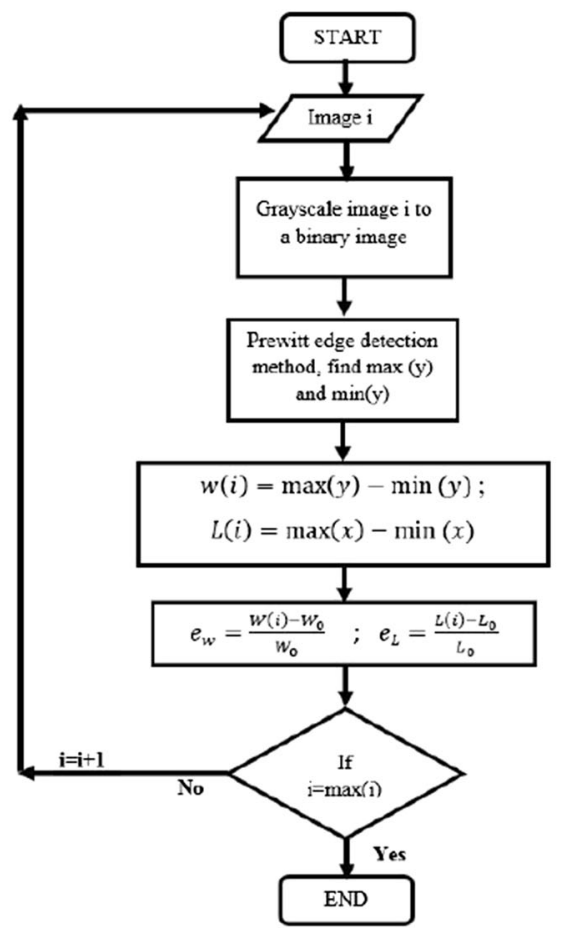

Open Access This article is distributed under the terms of the Creative Commons Attribution 4.0 International License (http:// creativecommons.org/licenses/by/4.0/), which permits unrestricted use, distribution, and reproduction in any medium, provided you give appropriate credit to the original author(s) and the source, provide a link to the Creative Commons license, and indicate if changes were made.

\section{References}

1. Tolouei R (2015) Carbon policies targeting road transport: is there a safety consequence. Trans Res Procedia 8:259-271

2. Kleiner M, Geiger M, Klaus A (2003) Manufacturing of lightweight components by metal forming. CIRP Ann Manuf Technol 52(2):521-542

3. Hu P, Ma N, Liu LZ, Zhu YG (2012) Theories, methods and numerical technology of sheet metal cold and hot forming: analysis, simulation and engineering applications. Springer, London. https:// doi.org/10.1007/978-1-4471-4099-3

4. Karbasian H, Tekkaya AE (2010) A review on hot stamping. J Mater Process Technol 210(15):2103-2118
5. Lin J, Liu Y (2003) A set of unified constitutive equations for modelling microstructure evolution in hot deformation. J Mater Process Technol 143-144:281-285

6. Lin J, Dean TA (2005) Modelling of microstructure evolution in hot forming using unified constitutive equations. J Mater Process Technol 167(2-3):354-362

7. Li N et al (2014) Damage investigation of boron steel at hot stamping conditions. Procedia Eng 81:1744-1749

8. Li N et al (2016) Experimental investigation of boron steel at hot stamping conditions. J Mater Process Technol 228:2-10

9. Lin YC, Li LT, Jiang YQ (2012) A phenomenological constitutive model for describing thermo-viscoplastic behavior of $\mathrm{Al}-\mathrm{Zn}-\mathrm{Mg}$ $\mathrm{Cu}$ alloy under hot working condition. Exp Mech 52(8):993-1002

10. Lin J (2015) Fundamentals of materials modelling for metals processing technologies: theories and applications. World Scientific Publishing Co Inc.

11. Shao Z et al (2016) Development of a new biaxial testing system for generating forming limit diagrams for sheet metals under hot stamping conditions. Exp Mech 56(9):1489-1500

12. Li N (2013) Fundamentals of materials modelling for hot stamping of UHSS panels with graded properties (Doctoral dissertation, $\mathrm{PhD}$ thesis, Department of Mechanical Engineering, Imperial College London) 
13. Cai J (2011) Modelling of phase transformation in hot stamping of boron steel (Doctoral dissertation, PhD thesis, Department of Mechanical Engineering, Imperial College London)

14. Ganapathy M et al (2015) Analysis of new Gleeble tensile specimen design for hot stamping application, 4th International Conference on New Forming Technology (ICNFT). E D P SCIENCES, pp 05013-05013. https://doi.org/10.1051/matecconf/20152105013

15. Ferguson DE, Lindeman NA (2006) Apparatus for an anvil system that provides enhanced self-resistive specimen heating when used in a dynamic thermo-mechanical material testing system. Google Patents

16. Pandi R, Yue S (1994) Dynamic transformation of austenite to ferrite in low carbon steel. ISIJ Int 34(3):270-279

17. Shao Z, Li N, Lin J, Dean TA (2017) Strain measurement and error analysis in thermo-mechanical tensile tests of sheet metals for hot stamping applications. Proc IME C J Mech Eng Sci. https://oi.org/ 10.1177/0954406217714011

18. Walsh D, Cieslak M, Savage W (1986) Temperature measurements in resistance heated specimens: longitudinal gradients. Weld J 65(7):184-192

19. Brown S, James J, Spittle J (1997) A 3D numerical model of the temperature-time characteristics of specimens tested on a gleeble thermomechanical simulator. Model Simul Mater Sci Eng 5(6):539

20. Norris S, Wilson I (1999) Application of 3D numerical modelling for thermal profile optimization on the Gleeble thermomechanical simulator. Model Simul Mater Sci Eng 7(3):297

21. Zupan M et al (2001) Development of high-temperature microsample testing. Exp Mech 41(3):242-247

22. Karanjgaokar NJ, Oh CS, Chasiotis I (2011) Microscale experiments at elevated temperatures evaluated with digital image correlation. Exp Mech 51(4):609-618

23. Lindeman NA (2008) Technique for applying direct resistance heating current to a specific location in a specimen under test while substantially reducing thermal gradients in the specimen gauge length. U.S. Patent No. 7,363,822

24. Shen $X$ et al (2010) Temperature analysis of specimens for Gleeble thermomechanical simulator. Heat Treat Met 35(9):122-125

25. Li Nan SZ, Jianguo L, Dean TA (2016) Investigation of Uniaxial Tensile Properties of AA6082 under HFQ ${ }^{\circledR}$ Conditions. In 16th international Metal Forming conference

26. Abspoel M, Neelis BM, van Liempt P (2016) Constitutive behaviour under hot stamping conditions. J Mater Process Technol 228: 34-42

27. Bailey C (2015) Structural material behavior in fire: steel: hot rolled carbon steel thermal properties. [cited 2015 27th March]; Available from: http://www.mace.manchester.ac.uk/project/research/ structures/strucfire/materialInFire/Steel/HotRolledCarbonSteel/ thermalProperties.htm

28. Properties of Pure Copper. Available from: http://www-ferp.ucsd. edu/LIB/PROPS/PANOS/cu.html

29. Datasheet (2015) Thermal Properoties of Calcium-Magnesium Silicate Thermal Insulation Sheet, U.R. online, Editor. http://uk.rsonline.com/web/p/thermal-insulating-sheets/7248909/

30. Kardoulaki E, et al. (2014) Investigation of the effects of thermal gradients present in Gleeble high-temperature tensile tests on the strain state for free cutting steel. The Journal of Strain Analysis for Engineering Design 0309324714531950

31. Jenner F et al (2014) Application of high-speed video extensometry for high-temperature tensile characterization of boron heat-treated steels. J Strain Anal Eng Des 49(6):378-387

32. BS EN ISO 6892-2 (2011) Metallic materials tensile testing. Part 2: method of test at elevated temperature. British Standards Institution

33. ASTM E21-09 (2009) Standard test methods for elevated temperature tension tests of metallic materials. ASTM International, West Conshohocken. https://doi.org/10.1520/E0021-09 